\title{
Predation by a Cuban Treefrog (Osteopilus septentrionalis) and a Domestic Cat (Felis catus) on Tropical House Geckos (Hemidactylus mabouia) in Central Cuba, with a Review of Predators and Vertebrate Prey of Tropical House Geckos
}

Rafael Borroto-Páez and Denise Reyes Pérez

Instituto de Geografía Tropical, Calle F No. 302, entre 13 y 15, Vedado, La Habana, Cuba (rborroto@geotech.cu)

$\mathrm{I}^{\mathrm{n}}$ n the Cuban Archipelago, the Cuban Treefrog (Osteopilus septentrionalis, Hylidae) is widely distributed on the main island and on at least 15 offshore islands, where it is relatively abundant (Estrada 2012; Rivalta González et al. 2014). The Cuban Treefrog is native to Cuba, the Cayman Islands, and at least eight Bahamian islands (Henderson and Powell 2009). It also has been introduced widely to many Caribbean Islands, Costa Rica, and the U.S. states of Florida, Georgia, and Hawaii (Owen et al. 2005; Henderson and Powell 2009; Powell et al. 2011, 2013). However, studies of this species focus largely on introduced rather than native populations (e.g., Meshaka 1996, 2001; Owen 2005; Smith 2005; Vargas Salinas 2006).

In Cuba, the Cuban Treefrog occupies both natural and anthropogenic habitats, in villages, rural, and urban areas, and often functions as a human commensal. It frequently is considered as a pest and can attain high indoor densities (e.g., personal observation of 4-6 individuals in a $2-\mathrm{m}^{2}$ bathroom). Cuban Treefrogs are voracious predators with a documented generalist diet that is highly plastic, consisting primarily of invertebrates, but small vertebrates such as frogs, lizards, and snakes are not uncommon (Meshaka 1996, 2001, 2011; Owen 2005; Glorioso et al. 2012) and cannibalism has been reported (Meshaka 2001; Kaiser et al. 2016; Borroto-Páez and Reyes 2019b).

Seven species of geckos have been introduced to Cuba, four of which are house geckos in the genus Hemidactylus. The Tropical House Gecko (H. mabouia) is the most abundant and widely distributed species in both urban and rural areas. It also functions as a human commensal (Borroto-Páez et al. 2015); sharing with the Cuban Treefrog walls, lights, and perches; however, few competitive interactions between the two species have been described. Herein we report predation on a Tropical House Gecko by a Cuban Treefrog (Osteopilus septentrionalis) and a domestic cat (Felis catus).

In August 2019, we stayed in a $140-\mathrm{m}^{2}$ fourth-floor apartment in Corralillo $\left(22^{\circ} 58^{\prime} 48^{\prime \prime} \mathrm{N}, 80^{\circ} 36^{\prime} 05^{\prime \prime} \mathrm{W}\right)$ in northern Villa Clara Province, Cuba. During our stay, we observed and counted at least five Cuban Treefrogs and eight Tropical House Geckos (three of them juveniles) in the apartment. During the night, an indoor light attracted nocturnal insects, principally lepidopterans. On several occasions, we observed both Cuban Treefrogs and Tropical House Geckos foraging for insects in the living room. Aware of the potential for competitive interactions, we kept cameras handy. At $1900 \mathrm{~h}$ on 22 August, we detected a Cuban Treefrog (SVL $52 \mathrm{~mm}$ ) perched on a curtain support. At $2100 \mathrm{~h}$, a young Tropical House Gecko (SVL $45 \mathrm{~mm}$ ) emerged from behind a picture frame (Fig. 1A). The gecko approached the frog (Figs. 1B-C), apparently without detecting a possible predator or lacking the experience to avoid the threat. When the gecko touched the frog, it immediately turned and captured and swallowed the gecko. This happened so quickly that we captured this event with only the tip of the gecko's tail protruding from the frog's mouth (Fig. 1D). A moment later, ingestion was complete (Fig. 1E).

Previous records of Osteopilus septentionalis preying on Hemidactylus mabouia (Meshaka 2004, 2011; Kingsland 2007; Voirin 2016) all occurred in Florida. To the best of our knowledge, no comparable predator-prey events have been reported in the native range of the Cuban Treefrog. However, because the two principals are both human commensals and 


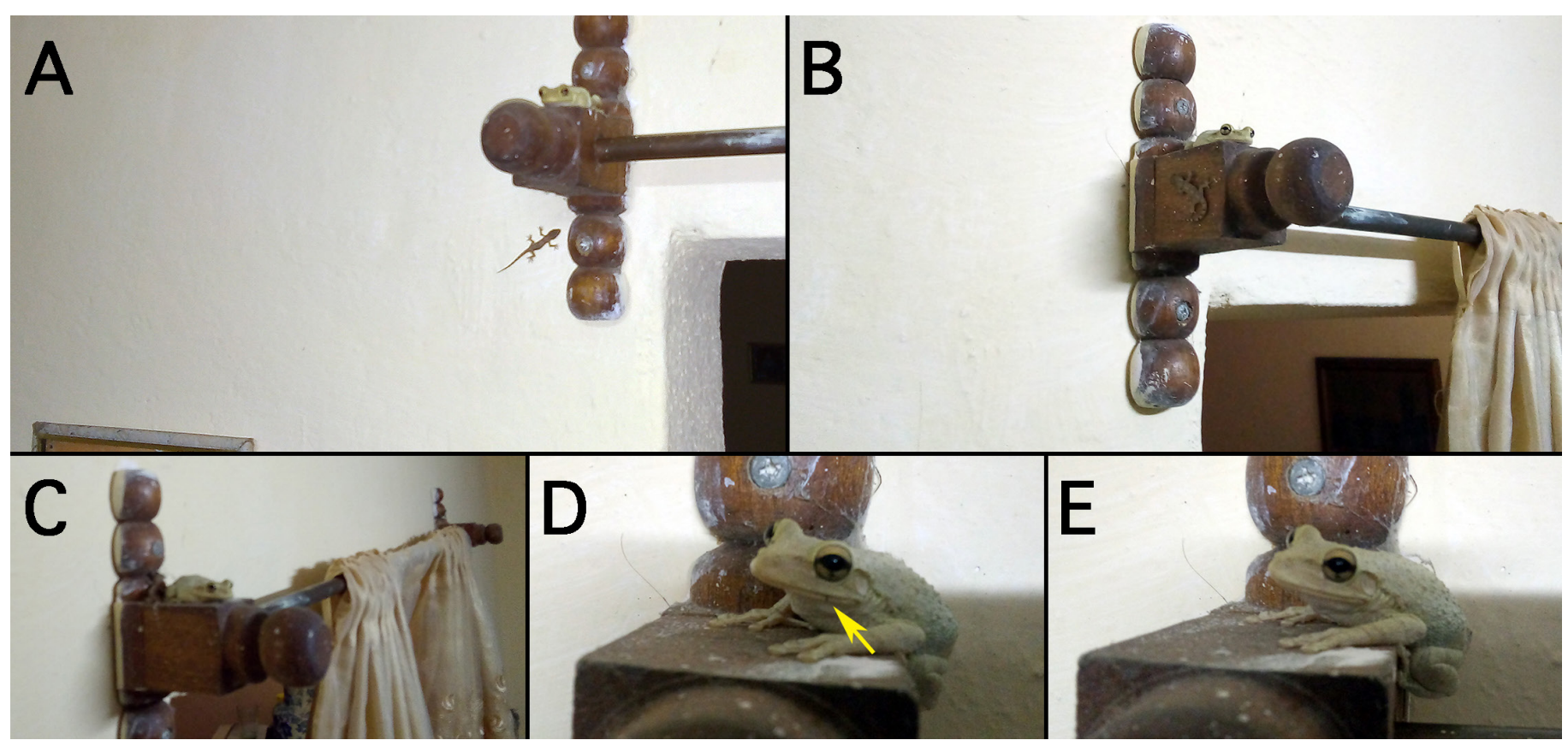

Fig. 1. A Cuban Treefrog (Osteopilus septentrionalis) preying on a young Tropical House Gecko (Hemidactylus mabouia). (A) The gecko approaches the curtain support after leaving its refuge under the picture frame in the lower left corner. (B) The gecko climbs onto the curtain support and (C) contacts the Cuban Treefrog, triggering the predation event. (D) An instant later, the Cuban Treefrog has ingested the gecko, with only the tip of its tail protruding from of the frog's mouth (arrow). (E) Ingestion is complete. Photographs by Rafael Borroto-Páez.

Table 1. A list of predators of Tropical House Geckos (Hemidactylus mabouia), updating lists in Nogueira et al. (2013) and Pedroso-Santos et al. (2019). Additions are marked with an asterisk $\left({ }^{*}\right)$.

\begin{tabular}{lll} 
Predator & Location & Reference(s) \\
\hline Arthropoda (Insecta, Arachnida, Myriapoda) & & \\
\hline Eciton Army Ants (Eciton burchellii) (Formicidae) & Brazil & Sazima (2015b)* \\
\hline Unidentified ctenid spider (Ctenidae) & Brazil & Lanschi and Ferreira (2012) \\
\hline Unidentified lycosid spider (Lycosidae) & Brazil & Koski et al. (2013) \\
\hline Hermit Spider (Nephilengys cruentata) (Nephilidae) & Brazil & Diniz (2011) \\
\hline Brick-red Pink-toed Spider (Avicularia variegata) (Theraphosidae) & Brazil & Queiroz-Almedia et al. (2019)* \\
\hline Amazonian Scorpion (Tityus metuendus) (Buthidae) & Brazil & Albuquerque (2012)* \\
\hline Unidentified camel spider (Solifugae) & Africa & Loveridge $(1947)^{*}$ \\
\hline Unidentified myriapod (centipede?) & Brazil & Pessoa $(2017)^{*}$ \\
\hline
\end{tabular}

\section{Chordata: Vertebrata (Amphibia)}

\begin{tabular}{lll}
\hline Granulated Toad (Rhinella major) (Bufonidae) & Brazil & Pedroso-Santos et al. (2019) \\
\hline Venezuelan Snouted Treefrog (Scinax x-signatus) (Hylidae) & Brazil & Zachi-Silva and Borges-Nojosa (2017) \\
\hline Cuban Treefrog (Osteopilus septentrionalis) (Hylidae) & Cuba & This paper* \\
\hline & Florida & $\begin{array}{l}\text { Meshaka et al. (2004)* Meshaka (2011)*; } \\
\text { Kingsland (2007)* Voirin (2016)* }\end{array}$ \\
\hline
\end{tabular}




\begin{tabular}{|c|c|c|}
\hline Predator & Location & Reference(s) \\
\hline \multicolumn{3}{|l|}{ Chordata: Vertebrata (Reptilia) } \\
\hline Antigua Bank Tree Anole (Anolis leachii) (Dactyloidae) & Barbuda & Trageser et al. (2018) \\
\hline Cuban Giant Anole (Anolis equestris) (Dactyloidae) & Florida & $\begin{array}{l}\text { Nicholson and Richards (1999)*; Thawley } \\
\text { et al. (2017)* }\end{array}$ \\
\hline \multirow[t]{2}{*}{ Puerto Rican Crested Anole (Anolis cristatellus) (Dactyloidae) } & Tortola (BVI) & Owen and Perry $(2005)^{*}$ \\
\hline & Florida & Mathes $(2020)^{*}$ \\
\hline Cuban Brown Anole (Anolis sagrei) (Dactyloidae) & Florida & Benoit et al. (2019)* \\
\hline North American Green Anole (Anolis carolinensis) (Dactyloidae) & Florida & Stroud and Sanger $(2020)^{*}$ \\
\hline Tropical House Gecko (Hemidactylus mabouia) (Gekkonidae) & Brazil, Tanzania & $\begin{array}{l}\text { Zamprogno and Teixeira (1998); Bonfigio } \\
\text { et al (2006)*; Pombal and Pombal-Jr. } \\
\text { (2010); Alburquerque et al. (2013)*; } \\
\text { Costa-Campos and Furtado (2013); } \\
\text { Lyakurwa (2017) }\end{array}$ \\
\hline Tokay Gecko (Gekko gecko) (Gekkonidae) & Florida & Meshaka et al. (2004)* \\
\hline Camaleãozinho (Enyalius perditus) (Leiosauridae) & Brazil & Muscat et al. (2016) \\
\hline Brazilian skink (Brasiliscincus agilis) (Mabuyidae) & Brazil & Vrcibradic and Rocha (2002) \\
\hline Brazilian whiptail (Glaucomastix littoralis) (Teiidae) & Brazil & Rocha et al. (2000), Menezes et al. (2006) \\
\hline Amazon Lava Lizard (Tropidurus torquatus) (Tropiduridae) & Brazil & $\begin{array}{l}\text { Araújo (1991); Rocha and Vrcibradic } \\
\text { (1998); Teixeira and Giovanelli (1999); } \\
\text { Galdino and Van Sluys (2004) }\end{array}$ \\
\hline Neotropical Lava Lizard (Tropidurus hispidus) (Tropiduridae) & Brazil & $\begin{array}{l}\text { Barbosa Da Silva et al. (2012)*; Souza } \\
\text { Pagel et al. (2020* }\end{array}$ \\
\hline \multirow[t]{2}{*}{ Nile Monitor (Varanus niloticus) (Varanidae) } & Africa & Loveridge $(1947)^{*}$ \\
\hline & Florida & Mazzoti et al. $(2020)^{*}$ \\
\hline Turks \& Caicos Boa (Chilabothrus chrysogaster chrysogaster) (Boidae) & Caicos Bank & Reynolds et al. (2017) \\
\hline Linnaeus's Sipo (Chironius exoletus) (Colubridae) & Brazil & Rodrigues (2007) \\
\hline Two-headed Sipo (Chironius bicarinatus) (Colubridae) & Brazil & Vrcibradic and Eisfeld (2016) \\
\hline Boettger's Sipo (Chironius flavolineatus) (Colubridae) & Brazil & Marques et al. (2016)* \\
\hline Giant Parrot Snake (Leptophis ahaetulla) (Colubridae) & Brazil & $\begin{array}{l}\text { Albuquerque et al. (2007); Germano and } \\
\text { França (2017) }\end{array}$ \\
\hline Cope's Parrot Snake (Leptophis depressirostris) (Colubridae) & Brazil & Thomas (1976) \\
\hline Green Vinesnake (Oxybelis fulgidus) (Colubridae) & Brazil & Santos-Jr. et al. (2011) \\
\hline Brown Vinesnake (Oxybelis aeneus) (Colubridae) & Brazil & Franzini et al. (2018) \\
\hline Emerald Snake (Hapsidophrys smaragdinus) (Colubridae) & Gabon & Pauwels et al. $(2017)^{*}$ \\
\hline Variegated Greensnake (Philothamnus semivariegatus) (Colubridae) & Africa & Loveridge $(1947)^{*}$ \\
\hline White-lipped Heraldsnake (Crotaphopeltis hotamboeia) (Colubridae) & Africa & Loveridge $(1947)^{*}$ \\
\hline \multirow[t]{2}{*}{ Puerto Rican Racer (Borikenophis portoricensis) (Dipsadidae) } & Peter Island (BVI) & Grant (1932) \\
\hline & Puerto Rico & Estrada and Borroto-Páez $(2020)^{*}$ \\
\hline Mona Racer (Borikenophis variegatus) (Dipsadidae) & Mona Island & M. Leal in Henderson and Sajdak (1996) \\
\hline Amaral's Groundsnake (Caaeteboia amarali) (Dipsadidae) & Brazil & Passos et al. (2012) \\
\hline Velvet Swampsnake (Erythrolamprus typhlus) (Dipsadidae) & Brazil & Da Silva et al. (2010) \\
\hline
\end{tabular}




\begin{tabular}{|c|c|c|}
\hline Predator & Location & Reference(s) \\
\hline Banded Cat-eyed Snake (Leptodeira annulata) (Dipsadidae) & Brazil & $\begin{array}{l}\text { Cantor and Pizzatto (2008); Hudson et al. } \\
(2019)^{*}\end{array}$ \\
\hline Fronted Groundsnake (Lygophis flavifrenatus) (Dipsadidae) & Brazil & $\begin{array}{l}\text { De Lema et al. (1983); Michaud and } \\
\text { Dixon (1989) }\end{array}$ \\
\hline Duméril's False Coralsnake (Oxyrhopus clathratus) (Dipsadidae) & Brazil & Morato (2005) \\
\hline Guibe’s Flamesnake (Oxyrhopus guibei) (Dipsadidae) & Brazil & Gavira et al. (2015)*; Gaiarsa et al. (2013)* \\
\hline Forest Flamesnake (Oxyrhopus petolarius) (Dipsadidae) & Brazil & Nogueiras et al. (2013) \\
\hline Amazon False Coralsnake (Oxyrhopus rhombifer) (Dipsadidae) & Brazil & Maschio et al. (2004)*; Assis et al. (2020)* \\
\hline Brazilian False Coralsnake (Oxyrhopus trigeminus) (Dipsadidae) & Brazil & Alencar et al. (2012) \\
\hline Paraguayan Green Racer (Philodryas nattereri) (Dipsadidae) & Brazil & $\begin{array}{l}\text { De Mesquita et al. (2011); Godinho et al. } \\
(2012)^{*}\end{array}$ \\
\hline Lichtenstein's Green Racer (Philodryas olfersii) (Dipsadidae) & Brazil & Thomas (1976) \\
\hline Patagonian Green Racer (Philodryas patagoniensis) (Dipsadidae) & Brazil & Barbo et al. (2011) \\
\hline Common Green Racer (Philodryas viridissima) (Dipsadidae) & Brazil & Jorge and Simoes $(2018)^{*}$ \\
\hline Panamanian Spotted Nightsnake (Siphlophis cervinus) (Dipsadidae) & Brazil & Martin and Oliveira $(1998)^{*}$ \\
\hline Guanabara Spotted Nightsnake (Siphlophis pulcher) (Dipsadidae) & Brazil & Sazima and Argôlo (1994) \\
\hline Worontzow's Spotted Nightsnake (Siphlophis worontzowi) (Dipsadidae) & Brazil & Bernarde and Abe (2010) \\
\hline Amazon Coastal House Snake (Thamnodynastes pallidus) (Dipsadidae) & Brazil & Rocha and Vrcibradic (1998) \\
\hline Coastal House Snake (Thamnodynastes strigatus) (Dipsadidae) & Brazil & Bernarde et al. (2000) \\
\hline Serra Snake (Tropidodryas serra) (Dipsadidae) & Brazil & De Oliveiras (2008) \\
\hline Jiboinha (Tropidodryas striaticeps) (Dipsadidae) & Brazil & De Oliveiras (2008) \\
\hline Striped House Snake (Boaedon lineatus) (Lamprophiidae) & Africa & Loveridge $(1947)^{*}$ \\
\hline East African Shovel-snouted Snake (Prosymna ambigua) (Prosymnidae) & Africa & Loveridge $(1953,1958)^{*}$; Pitman $(1974)^{*}$ \\
\hline Two-striped Sandsnake (Psammophis biseriatus) (Psammophiidae) & Kenya & Cottone and Bauer $(2008)^{*}$ \\
\hline Spotted Brown Trope (Tropidophis pardalis) (Tropidophiidae) & Cuba & Armas and Iturreaga $(2017)^{*}$ \\
\hline Southern Coralsnake (Micrurus frontalis) (Elapidae) & Brazil & De Lema et al. (1983) \\
\hline Alcatrazes Lancehead (Bothrops alcatraz) (Viperidae) & Brazil & Marques et al. (2002) \\
\hline Golden Lancehead (Bothrops insularis) (Viperidae) & Brazil & Duarte et al. (1995) \\
\hline Jaracara (Bothrops jararaca) (Viperidae) & Brazil & $\begin{array}{l}\text { Sazima (1992); Barbo (2008); Barbo et al. } \\
\text { (2011) }\end{array}$ \\
\hline
\end{tabular}

\section{Chordata: Vertebrata (Aves)}

Roadside Hawk (Rupornis magnirostris) (Accipitridae)

Smooth-billed Ani (Crotophaga ani) (Cuculidae)

Guira Cuckoo (Guira guira) (Cuculidae)
Brazil

Brazil

Brazil
De Macêdo and Freire (2010)

Figueiredo-de-Andrade and Silveira (2012)

Aurora (2011)*; Crivellari (2014)*; Fenalti (2014)*; Andrade et al. (2015); Branco (2018)*; Rodrigues et al. (2019)*

Straight-billed Woodcreeper (Dendroplex picus) (Dendrocolaptidae) Common Kestrel (Falco tinnunculus) (Falconidae)

Black-billed Scythebill (Campylorhamphus falcularius) (Furnariidae)
Brazil

Africa

Brazil
Loveridge (1947)*

Vecchi and Harding (2016)*
Vieira (2019)* 


\begin{tabular}{lll} 
Predator & Location & Reference(s) \\
\hline Pearly-eyed Thrasher (Margarops fuscatus) (Mimidae) & Guana (BVI) & J. Lazell in Henderson and Powell (2009)* \\
\hline White-banded Mockingbird (Mimus triurus) (Mimidae) & Argentina & Montero (2018)* \\
\hline Burrowing Owl (Athene cunicularia) (Strigidae) & Brazil, Ecuador & $\begin{array}{l}\text { Silva-Porto and Cerqueira (1990)*; Motta } \\
\text { Junior (1996); Vieira and Teixeira } \\
(2008)^{*} ; \text { Rodríguez Reyes (2015)* }\end{array}$ \\
\hline Pale-breasted Thrush (Turdus leucomelas) (Turdidae) & & Sazima and D'Angelo (2011)* \\
\hline Great Kiskadee (Pitangus sulphuratus) (Tyrannidae) & Brazil & $\begin{array}{l}\text { Gruber (2011)*; Pereira and Melo (2012)*; } \\
\text { Sazima (2015a)*; Dvojak (2017)* }\end{array}$ \\
\hline
\end{tabular}

\begin{tabular}{lll}
\hline Chordata: Vertebrata (Mammalia) & & \\
\hline Black-pencilled Marmoset (Callithrix penicillata) (Callitrichidae) & Brazil & Rocha-Santos et al. (2013) \\
\hline Silvery Marmoset (Mico argentatus) (Callitrichidae) & Brazil & Mourthe and Varga Lopes (2019)* \\
\hline Domestic Cat (Felis catus) (Felidae) & Mozambique & Peck et al. (2008)* \\
\hline Heart-nosed Bat (Cardioderma cor) (Megadermatidae) & Cuba & This paper* \\
\hline Fringe-lipped Bat (Trachops cirrhosis) (Phillostomidae) & Kenya & Wojnowski and Selempo (2005)* \\
\hline
\end{tabular}

frequently coexist, predation events like that described above must be more frequent than reports would indicate.

When we asked the residents of the other five apartments in the building, all but one described situations similar to what we encountered. Only one ground-floor apartment was free of geckos, almost certainly because a cat (Felis catus) lived in that apartment. The resident described several occasions when the cat had hunted and eaten geckos in the apartment. The apparent absence of Tropical House Geckos suggests that a single cat can control a gecko population better than several Cuban Treefrogs.

Reports of predation on Tropical House Geckos usually are based on fortuitous observations of ephemeral nocturnal events. In Table 1, we update the list of predators provided previously by Nogueira et al. (2013) and Pedroso-Santos et al. (2019). We compiled new additions to those lists using internet searches in Google Scholar for keywords including "predation," "prey," "gekkonid lizards," "tropical house gecko," "Hemidactylus," "mabouia," and various combinations with names of previously recorded predators. Because natural history notes in Herpetological Review frequently record predation events, we searched for the keyword "mabouia" in all issues. In some instances, predators were listed without citing any evidence; those were omitted. Nevertheless, we added 39 new predators and 66 new events. The most frequent predators were vertebrates (73), mostly species of snakes (41), followed by lizards (13), birds (11), mammals (5), and frogs (3). Only eight records documented invertebrate predation. By far the most records and predator species were from Brazil (57), whereas, for example, only nine species and ten observations occurred on islands in the Greater Caribbean. More reports documented predation by native predators (77 species and 104 reports) than by introduced predators (9 and 17), which suggests that Tropical House Geckos could play an important role as prey to at least some native species. However, whether those predator interactions are beneficial or harmful to native ecosystems will require additional research, especially since little is known about the risks posed by exotic diseases and parasites dispersed by invasive species (e.g., Kraus 2009; Barnett et al. 2018).

Many undocumented reports record predation by Tropical House Geckos on insects, arachnids, and other invertebrates (most frequently nocturnal lepidopterans, cockroaches, crickets, myriapods, isopods, etc.), but most lack documentation of species and only a few provide actual evidence. Except for the six cases of cannibalism in $H$. mabouia (Table 1 ), only eight reports ( 6 of them from islands in the Greater Caribbean) document predation on small vertebrates (Table 2).

The role of Tropical House Geckos as prey (81 recorded predators; Table 1) contrasts sharply with their role as predator (8 recorded examples of vertebrate prey; Table 2 ). However, this apparent imbalance is largely attributable to the many records of unidentified invertebrates consumed by Tropical House Gecko (and not considered herein), despite the reality that invertebrates comprise nearly $99 \%$ of all animal diversity (Ponder and Lunney 1999).

These updated lists of Tropical House Geckos as predators and prey may be useful for guiding future studies on the feeding ecology of this widely introduced gecko with native species. Furthermore, although reports are sparse, the abundance and densities of introduced geckos suggest that they likely engage in many other interactions with native species. 
Table 2. List of vertebrate prey taken by Tropical House Geckos (Hemidactylus mabouia).

\begin{tabular}{lll} 
Prey & Location & Reference(s) \\
\hline Unidentified frog (Eleutherodactylus sp.) & Puerto Rico & Rivero (1978) \\
\hline White-headed Dwarf Gecko (Lygodactylus mombasicus) & Africa & Loveridge (1947) \\
\hline Unidentified gecko (Sphaerodactylus sp.) & Puerto Rico & Rivero (1978) \\
\hline Venezuelan Coastal Clawed Gecko (Gonatodes antillensis) & Curaçao & Dornburg et al. (2011), Lamb et al. (2020) \\
\hline Dutch Leaf-toed Gecko (Phyllodactylus martini) & Curaçao & Dornburg et al. (2011), Lamb et al. (2020) \\
\hline Unidentified anole (Anolis sp.) & Puerto Rico & Rivero (1978) \\
\hline Unidentified anole hatchling (Anolis sp.) & Florida & CISEH (2018) \\
\hline Brahminy Blindsnake (Indotyphlops braminus) & Curaçao & Lamb et al. (2020) \\
\hline
\end{tabular}

For example, competitive interactions of Tropical House Geckos with native Caribbean lizards have been described by Powell and Henderson (1992), Powell (2003), Stroud (2013), and Borroto-Páez and Reyes (2019a). A better understanding of the various roles filled by these invasive geckos is necessary for the development of management plans for their mitigation and control.

\section{Acknowledgements}

We thank Boris A. Fabres, Environmental Protection in the Caribbean (EPIC), for reviewing an early version of this manuscript and providing useful suggestions. We thank Robert Powell, Avila University; Walter E. Meshaka, State Museum of Pennsylvania; and Robert W. Henderson, Milwaukee Public Museum, for providing references.

\section{Literature Cited}

Albuquerque, S. de. 2012. Hemidactylus mabouia (Wood Slave). Predation. Herpetological Review 43: 646-647.

Albuquerque, N.R. de, U. Galatti, and M. Di-Bernardo. 2007. Diet and feeding behaviour of the neotropical parrot snake (Leptophis ahaetulla) in northern Brazil. Journal of Natural History 41: 1237-1243.

Albuquerque, N.R. de, A. da Silva Costa-Urquiza, M. Pereira Soares, L. Saucedo Alves, and M.V.S. Urquiza. 2013. Diet of two sit-and-wait lizards, Phyllopezus pollicaris (Spix, 1825) (Phyllodactylidae) and Hemidactylus mabouia (Moreau de Jonnès, 1818) (Gekkonidae) in a perianthropic area of Mato Grosso do Sul, western Brazil. Biota Neotropical 13: 376-381.

Alencar, L.R.V., C.A.B. Galdino, and L.B. Nascimento. 2012. Life history aspects of Oxyrhopus trigeminus (Serpentes: Dipsadidae) from two sites in southeastern Brazil. Journal of Herpetology 46: 9-13.

Andrade, R.A., Y.F. Siqueira, and D.C. Passos. 2015. Predation of Hemidactylus mabouia (Squamata: Gekkonidae) by Guira guira (Cuculiformes: Cuculidae) in northeastern Brazil. Boletim do Museu de Biologia Mello Leitão (Nova Série) 37: 201-206.

Araújo, A.F.B. 1991. Structure of a white sand-dune lizard community of coastal Brazil. Revista Brasileira de Biologia 51: 857-865.

Armas, L.F. de and M. Iturreaga. 2017. Depredación de Hemidactylus mabouia (Squamata: Gekkonidae) por Tropidophis pardalis (Serpentes: Tropidophiidae). Novitates Caribaea 11: 99-102.

Assis, C.L., J.J.M. Guedes, L.M.G. Jesus, and R.N. Feio. 2020. New defensive behaviour of the false coral snake Oxyrhopus rhombifer Duméril, Bibron \& Duméril, 1854 (Serpentes, Dipsadidae) in south-eastern Brazil. Neotropical Biology and Conservation 15: 71-76.

Aurora, C. 2011. [WA334017, Guira guira (Gmelin, 1788)]. Wiki Aves - A Enciclopédia das Aves do Brasil. <http://www.wikiaves.com/334017>.
Barbo, F.E. 2008. Os répteis no município de São Paulo: aspectos históricos, diversidade e conservação, pp. 236-269. In: L.R. Malagoli, F.B. Bajesteiro, and M. Whately (eds.), Além do Concreto: Contribuiçōes para a Proteçāo da Biodiversidade Paulistana. Instituto Socioambiental, São Paulo, Brazil.

Barbo, F.E., O.A.V. Marques, and R.J. Sawaya. 2011. Diversity, natural history, and distribution of snakes in the municipality of São Paulo. South American Journal of Herpetology 6: 135-160.

Barbosa Da Silva, L., J. Bezerra Da Silva, S.L. Da Silva Muniz, E. Maranhão Dos Santos, and G.J. Barbosa De Moura. 2012. Hemidactylus mabouia (Wood Slave). Predation. Herpetological Review 43: 647.

Barnett, L.K., B.L. Phillips, A.C.G. Heath, A. Coates, and C.J. Hoskin. 2018. The impact of parasites during range expansion of an invasive gecko. Parasitology 145: 1400-1409.

Benoit, E.R., T. Carney, and T. Benoit. 2019. Anolis sagrei (Brown Anole). Predation. Herpetological Review 50: 137-138.

Bernarde, P.S., J.C. Moura-Leite, R.A. Machado, and M.N.C. Kokobum. 2000. Diet of the colubrid snake, Thamnodynastes strigatus (Günther, 1858) from Paraná State, Brazil, with field notes on anuran predation. Revista Brasileira de Biologia 60: 695-699.

Bernarde, P.S. and A.S. Abe. 2010. Hábitos alimentares de serpentes em Espigão do Oeste, Rondônia, Brasil. Biota Neotropica 10: 167-173.

Bonfiglio, F., R.L. Balestrin, and L.H. Cappellari. 2006. Diet of Hemidactylus mabouia (Sauria, Gekkonidae) in urban area of Southern Brazil. Biociências 14: 107-111.

Borroto-Páez, R., R. Alonso Bosch, B.A. Fabres, and O. Alvarez García. 2015. Introduced amphibians and reptiles in the Cuban Archipelago. Herpetological Conservation and Biology 10: 985-1012.

Borroto-Páez, R. and D. Reyes Perez. 2019a. Competitive interference between the endemic Cuban Green Anole (Anolis porcatus) and invasive Tropical House Geckos (Hemidactylus mabouia). Reptiles \& Amphibians 26: 43-46.

Borroto-Páez, R. and D. Reyes Pérez. 2019b. Unusual behavior during cannibalism of Cuban Treefrogs (Osteopilus septentrionalis) in a commensal habitat in Cuba. Reptiles \& Amphibians 26: 117-118.

Branco, E. 2018. Guira guira. Biofaces. <http://www.biofaces.com/post/112183/ anu-branco/s.

Cantor, M. and L. Pizzatto. 2008. Leptodeira annulata (Banded Cat-eyed Snake). Diet. Herpetological Review 39: 470-471.

CISEH (Center for Invasive Species and Ecosystem Health). 2018. University of Georgia - Center for Invasive Species and Ecosystem Health, USDA Animal and Plant Health Inspection Service, USDA Forest Service, USDA Identification Technology Program, and USDA National Institute of Food and Agriculture, Tifton, Georgia. <http://www.invasive.org>.

Costa-Campos, C.E. and M.F.M. Furtado. 2013. Hemidactylus mabouia (Tropical House Gecko). Cannibalism. Herpetological Review 44: 673-674.

Cottone, A.M. and A.M. Bauer. 2008. Psammophis biseriatus (Link-marked Sand Snake). Diet. Herpetological Review 39: 99.

Crivellari, A.C. 2014. [WA530128, Guira guira (Gmelin, 1788)]. WikiAves - A Enciclopédia das Aves do Brasil. <http://www.wikiaves.com/530128>.

Da Silva, M.V., M. B. De Souza, and P.S. Bernarde. 2010. Riqueza e dieta de serpentes do Estado do Acre, Brasil. Revista Brasileira de Zoociências 12: 165-176. 
De Lema, T., M.L. De Araújo, and A.C.P. Azevedo. 1983. Contribuição ao conhecimento da alimentação e do modo alimentar de serpentes do Brasil. Comunicações do Museu de Ciências e Tecnologia PUCRS 26: 41-121.

De Macêdo, B.R.M. and E.M.X. Freire. 2010. Hemidactylus mabouia (Tropical House Gecko). Predation. Herpetological Review 41: 492-493.

De Mesquita, P.C.M.D., D.M. Borges-Nojosa, D.C. Passos, and C.H. Bezerra. 2011. Ecology of Philodryas nattereri in the Brazilian semi-arid region. Herpetological Journal 21: 193-198.

De Oliveira, F.S. 2008. Ecologia alimentar e reprodutiva de duas espécies de Tropidodryas (Serpentes, Colubridae) da Mata Atlântica. Dissertação de Mestrado, Universidade de São Paulo, São Paulo, Brazil.

Diniz, S. 2011. Predation and feeding on the tropical house gecko Hemidactylus mabouia (Squamata: Gekkonidae) by the giant orb-weaver spider Nephilengys cruentata (Araneae: Nephilidae). Herpetology Notes 4: 357-358.

Dornburg, A., D. L. Warren, T. Iglesias, and M. C. Brandley. 2011. Natural history observations of the ichthyological and herpetological fauna on the island of Curaçao (Netherlands). Bulletin of the Peabody Museum of Natural History 52: $181-186$.

Dornburg, A., C. Lippi, S. Federman, J.A. Moore, D.L. Warren, T.L. Iglesias, M.C. Brandley, G.J. Watkins-Colwell, A.D. Lamb, and A. Jones. 2016. Disentangling the influence of urbanization and invasion on endemic geckos in tropical biodiversity hot spots: A case study of Phyllodactylus martini (Squamata: Phyllodactylidae) along an urban gradient in Curaçao. Bulletin of the Peabody Museum of Natural History 57: 147-164.

Duarte, M.R., G. Puorto, and F.L. Franco. 1995. A biological survey of the pitviper Bothrops insularis Amaral, 1921 (Serpentes, Viperidae): an endemic and threatened offshore island snake of southeastern Brazil. Studies on Neotropical Fauna \& Environment 30: 1-13.

Dvojak, I. 2015. Pitangus sulphuratus - Ficha de la especie. EcoRegistros. <http:// www.ecoregistros.org>.

Estrada, A.R. 2012. The Cuban Archipelago, pp. 113-125. In: R. Powell and R.W. Henderson (eds.), Island lists of West Indian amphibians and reptiles. Bulletin of the Florida Museum of Natural History 51: 85-166.

Estrada, A.R. and R. Borroto-Páez. 2020. The Puerto Rican Racer (Borikenophis portoricensis) using two invasive species as resources: Australian Pines (Casuarina equisetifolia) as refuge and house geckos (Hemidactylus sp.) as prey. Reptiles \& Amphibians 26: 230-231.

Fenalti, P.R. 2014. WA566869, Guira guira (Gmelin, 1788). WikiAves - A Enciclopédia das Aves do Brasil. <http://www.wikiaves.com/566869>.

Figueiredo de Andrade, C.A. and A.L. Silveira. 2012. Hemidactylus mabouia (Tropical House Gecko). Predation. Herpetological Bulletin 121: 37-38.

Franzini, L.D., C.K.B. Pedro, L.B.Q. Cavalcanti, and D.O. Mesquita. 2018. Predation of Hemidactylus mabouia (Sauria: Gekkonidae) by a vine snake Oxybelis aeneus (Serpentes: Colubridae) in an Atlantic Forest fragment, northeastern Brazil. Pesquisa e Ensino em Ciências Exatas e da Natureza 2: 67-70.

Gaiarsa, M.P., L.R.V. de Alencar, and M. Martins. 2013. Natural history of pseudoboine snakes. Papéis Avulsos de Zoologia 53: 261-283.

Galdino, C.A.B. and M. Van Sluys. 2004. Tropidurus torquatus (Collared Lizard, Calango). Saurophagy. Herpetological Review 35: 173.

Gavira, R.S.B., A. Fabrício-Neto, and D.V. Andrade. 2015. Death of a juvenile false coral snake, Oxyrhopus guibei (Hoge \& Romano, 1977) (Serpentes: Dipsadidae), after ingesting a tropical house gecko, Hemidactylus mabouia (Moreau de Jonnès, 1818) (Sauria: Gekkonidae) Herpetology Notes 8: 153-154.

Germano, C.E.S. and F.G.R. França. 2017. Leptophis ahaetulla (Parrot Snake). Diet and Mortality. Herpetological Review 48: 452.

Glorioso, B.M., J.H. Waddle, M.W. Crockett, K.G. Rice, and H.F. Percival. 2012. Diet of the invasive Cuban Treefrog (Osteopilus septentrionalis) in pine rockland and mangrove habitats in south Florida. Caribbean Journal of Science 46: 346-355.

Godinho, L.B., M. Ribeiro Moura, M.A. Peixoto, and R. Neves Feio. 2012. Notes on the diet of Philodryas nattereri (Squamata: Colubridae) in southeastern Brazil. Salamandra 48: 233-234.

Grant, C. 1932. Herpetology of Tortola; notes on Anegada and Virgin Gorda, British Virgin Islands. Journal of the Department of Agriculture of Puerto Rico 16: 339-346.

Gruber, J. 2011. WA483771, Pitangus sulphuratus (Linnaeus, 1766). Wiki Aves - A Enciclopédia das Aves do Brasil. <http://www.wikiaves.com/483771>.

Henderson, R.W. and R. Powell. 2009. Natural History of West Indian Reptiles and
Amphibians. University of Florida Press, Gainesville, Florida.

Henderson, R.W. and R.A. Sajdak. 1996. Diets of West Indian racers (Colubridae: Alsophis): Composition and biogeographic implications, pp. 327-338. In: R. Powell and R.W. Henderson (eds.), Contributions to West Indian Herpetology: A Tribute to Albert Schwartz. Society for the Study of Amphibians and Reptiles, Ithaca, New York.

Hudson, A.A., N.R. Honório, and M.S. Bernadete. 2019. Leptodeira annulata (Banded Cat-Eyed Snake). Diet and Reproduction. Herpetological Review 50: $160-161$.

Jorge, R.F. and P.I. Simōes. 2018. Philodryas viridissima (Common Green Racer). Diet. Herpetological Review 49: 761-762.

Kaiser, H., M.C. Chamberlain, T. Edwards, J.R. Nuñez, T.M. Rodríguez-Cabrera, and J. Torres. 2016. Cannibalism in Cuba: First direct observations of Cuban Treefrogs (Osteopilus septentrionalis, Hylidae) feeding on conspecifics in their native habitat, with a brief review of anurophagy and cannibalism in treefrogs. Reptiles \& Amphibians 23: 21-27.

Kingsland, K. 2007. Assemblage dynamics of exotic herpetofauna on Jupiter campus of Florida Atlantic University. Unpublished Honors Thesis, Florida Atlantic University, Boca Raton, Florida.

Koski, D.A., A.P.V Koski, L. Merçon, and Y.F. Messas. 2013. Hemidactylus mabouia (Tropical House Gecko). Predation. Herpetological Review 44: 509.

Kraus, F. 2009. Alien Reptiles and Amphibians: A Scientific Compendium and Analysis. Invading Nature: Springer Series in Invasion Biology 4. Springer, Dordrecht, The Netherlands.

Lamb, A.D., C.A. Lippi, G.J. Watkins-Colwell, A. Jones, D. Warren, T.L. Iglesias, M. Brandley, C. Neagle, and A. Dornburg. 2020. What makes Hemidactylus invasions successful? A case study 1 on the island of Curaçao. bioRxiv preprint. <https://doi.org/10.1101/2020.04.17.047209>.

Lanschi, F.A. and R.B. Ferreira. 2012. Hemidactylus mabouia (Tropical House Gecko). Predation. Herpetological Review 43: 133-134.

Leal, E.S.B., L. da S. Chaves, J.G. do Prado Neto, P.B. de Passos Filho, D. de F. Ramalho, D. de Q. Guerra Filho, R. de Lyra-Neves, W.R. Telino-Júnior, and G.J.B. de Moura. 2018. What constitutes the menu of Trachops cirrhosus (Chiroptera)? A review of the species' diet. Neotropical Biology and Conservation 13: 337-346.

Loveridge, A. 1947. Revision of the African lizards of the family Gekkonidae. Bulletin of the Museum of Comparative Zoology 98: 1-469.

Loveridge, A. 1953. Zoological results of a fifth expedition to East Africa. III. Reptiles from Nyasaland and Tete. Bulletin of the Museum of Comparative Zoology 110: 141-322.

Loveridge, A. 1958. Revision of five African snake genera. Bulletin of the Museum of Comparative Zoology 119: 1-198.

Lyakurwa, J.V. 2017. Hemidactylus mabouia (Tropical House Gecko). Cannibalism. Herpetological Review 48: 646.

Marques, O.A.V., M. Martins, and I. Sazima. 2002 A new insular species of pitviper from Brazil, with comments on evolutionary biology and conservation of the Bothrops jararaca group (Serpentes, Viperidae). Herpetologica 58: 303-312.

Marques, R., K. Mebert, É. Fonseca, D. Rödder, M. Solé, and M.S. Tinôco. 2016. Composition and natural history notes of the coastal snake assemblage from Northern Bahia, Brazil. ZooKeys 611: 93-142.

Martins, M. and M.E. Oliveira. 1998. Natural history of snakes in forests of the Manaus Region, Central Amazonia, Brazil. Herpetological Natural History 6(2): 78-150.

Maschio, G.F., M. Di-Bernardo, and J. Melchiors. 2004. Oxyrhopus rhombifer rhombifer (NCN). Diet. Herpetological Review 35: 71.

Mathes, C.C. 2020. Anolis cristatellus (Puerto Rican Crested Anole) and Hemidactylus mabouia (Tropical House Gecko). Diet and predation. Herpetological Review 51: 325-326.

Mazzotti, F.J., J.H. Nestler, J.M. Cole, C. Closius, W.H. Kern, M.R. Rochford, E. Suarez, R. Brubaker, S.G. Platt, T. Rainwater, and J.K. Ketterlin. 2020. Diet of Nile Monitors (Varanus niloticus) removed from Palm Beach and Broward Counties, Florida, USA. Journal of Herpetology 54: 189-195.

Menezes, V.A., V.C. Amaral, M.V. Sluys, and C.F.D. Rocha. 2006. Diet and foraging of the endemic lizard Cnemidophorus littoralis (Squamata, Teiidae) in the Restinga de Jurubatiba, Macaé, RJ. Brazilian Journal of Biology 66: 803-807.

Meshaka, W.E., Jr. 1996. Diet and colonization of buildings by the Cuban Treefrog, Osteopilus septentrionalis (Anura: Hylidae). Caribbean Journal of Science 32: 59-63. 
Meshaka, W.E., Jr. 2001. The Cuban Treefrog in Florida: Life History of a Successful Colonizing Species. University of Florida Press, Gainesville, Florida.

Meshaka, W.E., Jr. 2011. A runaway train in the making: The exotic amphibians, reptiles, turtles, and crocodilians of Florida. Monograph 1. Herpetological Conservation and Biology 6: 1-101.

Meshaka, W.E., Jr., B.P. Butterfield, and J.B. Hauge. 2004. The Exotic Amphibians and Reptiles of Florida. Krieger Publishing Company, Malabar, Florida.

Michaud, E.J. and J.R. Dixon. 1989. Prey items of 20 species of the neotropical colubrid snake genus Liophis. Herpetological Review 20: 39-41.

Montero, M. 2018. Mimus triurus - Ficha de la especie. Ecoregistros. <http://www. ecoregistros.org>.

Morato, S.A.A. 2005. Serpentes da Região Atlântica do Estado do Paraná, Brasil: Diversidade, Distribuição e Ecologia. Tese de Doutorado, Universidade Federal do Paraná, Curitiba. Brazil.

Motta-Junior, J.C. 1996. Ecologia alimentar de corujas (Aves, Strigiformes) na regiāo central do estado de São Paulo: biomassa, sazonalidade e seletividade de suas presas. Unpublished Ph.D. thesis, Universidade Federal de São Carlos, São Carlos, Brazil.

Mourthe, I. and E. Varga Lopes. 2019. Iguana iguana (Common Green Iguana). Predation. Herpetological Review 50: 785-786.

Muscat, E., E. Rotenberg, and I.F. Machado. 2016. An unusual event of vertebrate predation by an insectivorous lizard. Neotropical Biology and Conservation 11: 192-194.

Nicholson K.E. and P.M. Richards. 1999. Observations of a population of Cuban Knight Anoles, Anolis equestris. Anolis Newsletter V: 95-98.

Nogueira, C.H.O., C.A. Figueiredo-de-Andrade, and N.N. Freitas. 2013. Death of a juvenile snake Oxyrhopus petolarius (Linnaeus, 1758) after eating an adult house gecko Hemidactylus mabouia (Moreau de Jonnès, 1818). Herpetology Notes 6: 39-43.

Owen, J.L. 2005. The Cuban Tree Frog (Osteopilus septentrionalis): Distribution, diet, and reproduction of an invasive species in the British Virgin Islands. Unpublished M.S. Thesis, Texas Tech University, Lubbock, Texas.

Owen, J.L. and G. Perry. 2005. Anolis cristatellus wileyae (Virgin Islands Crested Anole). Saurophagy. Herpetological Review 36: 444.

Owen, J.L., G. Perry, J. Lazell, C. Petrovic, and J. Egelhoff. 2005. Geographic distribution. Osteopilus septentrionalis (Cuban Tree Frog). Herpetological Review 36: 76.

Passos, P., L. Ramos, and D.N. Pereira. 2012. Distribution, natural history, and morphology of the rare snake, Caaeteboia amarali (Serpentes: Dipsadidae). Salamandra 48: 51-57.

Pauwels, O.S.G., T.B. Bi Essono II, P. Carlino, L. Chirio, B. Huijbregts, T.E.J. Leuteritz, D. Rousseaux, E. Tobi, C. Vigna, and W. Van Neer. 2017. Miscellanea Herpetologica Gabonica VII. Bulletin of the Chicago Herpetological Society 52: 1-7.

Peck, D.R., L. Faulquier, P. Pinet, S. Jaquemet, and M. Le Corre. 2008. Feral cat diet and impact on sooty terns at Juan de Nova Island, Mozambique Channel. Animal Conservation 11: 65-74.

Pedroso-Santos, F., P. Ribeiro Sanches, J. Cleiton Sousa, and C.E. Costa-Campos. 2019. Predation on the Tropical House Gecko Hemidactylus mabouia (Squamata: Gekkonidae) by the Granular Toad Rhinella major (Anura: Bufonidae), including an updated list of predation events in this species of gecko. Herpetology Notes 12: 833-839.

Pessoa, W. 2017. Unidentified Myriapod. Biofaces. <http://www.biofaces.com/ post/84971/lacraia-predando-lagarto/>

Pereira, Z. da P. and C. Melo. 2012. Nestling's pellets of the Great Kiskadee (Pitangus Sulphuratus) in Brazilian urban environment. Ornitologia Neotropical 23: 269-276.

Pitman, C.R.S. 1974. A Guide to the Snakes of Uganda. Revised edition. Wheldon and Wesley, Codicote, England.

Pombal, R. and J.P. Pombal, Jr. 2010. Hemidactylus mabouia (Tropical House Gecko). Cannibalism. Herpetological Review 41: 223-224.

Ponder W.F. and D. Lunney (eds.). 1999. The Other 99\%: The Conservation and Biodiversity of Invertebrates. Royal Zoological Society of New South Wales, Mosman, Australia.

Powell, R. 2003. Species profile: Utila's reptiles. Iguana 10: 36-38.

Powell, R. and R.W. Henderson. 1992. Anolis gingivinus. Nocturnal behavior. Herpetological Review 23: 117.
Powell, R., R.W. Henderson, M.C. Farmer, M. Breuil, A.C. Echternacht, G. van Buurt, C.M. Romagosa, and G. Perry. 2011. Introduced amphibians and reptiles in the Greater Caribbean: Patterns and conservation implications, pp. 63-143. In: A. Hailey, B.S. Wilson, and J.A. Horrocks (eds.), Conservation of Caribbean Island Herpetofaunas. Volume 1: Conservation Biology and the Wider Caribbean. Brill, Leiden, The Netherlands.

Powell, R., R.W. Henderson, G. Perry, M. Breuil, and C.M. Romagosa. 2013. Introduced amphibians and reptiles in the Lesser Antilles, pp. 74-107. In: J.-L. Vernier and M. Burac (eds.), Biodiversité Insulaire: la Flore, la Faune et l'Homme dans les Petites Antilles. Actes du Colloque international, Schoelcher, 8-10 Novembre 2010. Direction de l'Environment, de l'Aménagement et du Logement de Martinique and Université de Antilles et de la Guyana, Schoelcher, Martinique.

Queiroz Almeida, M., R. Sobral, A. Moreira Da Silva-Neto, and D.M.M. Mendes. 2019. Hemidactylus mabouia (Tropical House Gecko). Predation. Herpetological Review 50: 577.

Reynolds, R.G., J. Burgess, G. Waters, and G.P. Gerber. 2017. Chilabothrus chrysogaster chrysogaster (Turks Island Boa). Diet. Herpetological Review 48: 857.

Rivalta González, V., L. Rodríguez Schettino, C.A. Mancina, and M. Iturriaga. 2014. Amphibians of Cuba: Checklist and geographic distribution. Smithsonian Herpetological Information Service 145: 1-48.

Rivero, J.A. 1978. Los Anfibios y Reptiles de Puerto Rico. The Amphibians and Reptiles of Puerto Rico. Universidad de Puerto Rico, Río Piedras, Puerto Rico.

Rocha, C.F.D., D. Vrcibradic, and A.F.B. Araújo. 2000. Ecofisiologia de répteis de restingas brasileiras, pp. 117-149. In: F.A. Esteves and L.D. Lacerda (eds.), Ecologia de Restingas e Lagoas Costeiras. Núcleo de Pesquisas Ecológicas de Macaé (NUPEM/UFRJ), Rio de Janeiro, Brazil.

Rocha, C.F.D. and D. Vrcibradic. 1998. Reptiles as predators and as preys in a restinga habitat of southeastern Brazil. Ciência \& Cultura 50: 364-368.

Rocha-Santos, G., E. Barbier, and D.F. Silva. 2013. Hemidactylus mabouia (African House Gecko). Predation. Herpetological Review 44: 674.

Rodrigues, M.G. 2007. Ecomorfologia e uso de recursos das espécies de Chironius (Serpentes: Colubridae) na Serra do Mar. Dissertação de Mestrado, Universidade Estadual Paulista, São José do Rio Preto, Brazil.

Rodrigues, M.T., R. Cumplido, D. Steinwender, D.B. Quintanilha, U.G. de Melo Jr., P. de Oliveira Paiva Quintanilha, and L.M. Diele-Viegas. 2019. Predation record of Tropical House Gecko (Hemidactylus mabouia) (Reptilia: Squamata: Gekkonidae) by Guira Cuckoo (Guira guira) (Aves: Cuculiformes: Cuculidae) in the region of Arraial do Cabo, east coast of Rio de Janeiro State, Brazil. Open Access Library Journal 6: e5289.

Rodríguez Reyes, E. 2015. Abundancia Relativa y dieta del Búho Terrestre Athene Cunicularia Punensis (Chapman, 1914) en las zonas circundantes de la comuna Atahualpa, Provincia de Santa Elena, Ecuador. Tesis para la obtención del Título de Biólogo, Facultad de Ciencias Naturales, Guayaquil, Ecuador.

Santos-Jr., A.P., B.H.A. Carneiro, P.R. Sarmento, and S. Ribeiro. 2011. First record of the house gecko Hemidactylus mabouia (Moreau de Jonnès, 1818) in the diet of the vine snake Oxybelis fulgidus (Daudin, 1803). Herpetology Notes 4: 429-430.

Sazima, I. 1992. Natural history of the Jararaca pitviper, Bothrops jararaca, in southeastern Brazil, pp. 199-216. In: J.A. Campbell and E.D. Brodie (eds.), Biology of the Pitvipers. Selva Publishing, Tyler, Texas.

Sazima I. 2015a. Tropical House Gecko (Hemidactylus mabonia) shelter raided by a single tyrannid bird (Pitangus sulphuratus) in an urban park. Herpetology Notes 8: 433-435.

Sazima I. 2015b. House Geckos (Hemidactylus mabouia) and an unidentified snake killed and devoured by army ants (Eciton burchellii). Herpetology Notes 8: 527-529.

Sazima, I. and A.J.S. Argolo. 1994. Siphlophis pulcher (NCN). Prey. Herpetological Review 25: 126.

Sazima, I. and G.B. D'Angelo. 2011. The Pale-breasted Thrush (Turdus leucomelas) preys on a gekkonid lizard and an anomalepidid snake. Revista Brasileira de Ornitologia 19: 450-452.

Silva-Porto, F. and R. Cerqueira. 1990. Seasonal variation in the diet of the burrowing owl Athene cunicularia in a restinga of Rio de Janeiro state. Ciência \& Cultura 42: 1182-1186.

Souza Pagel, G., A. Kaufer Leite, L. Costa C. de Oliveira, and M. Santos Tinoco. 2020. Tropidurus hispidus (Neotropical Lava Lizard). Diet. Herpetological Review 51: 134 
Smith, K.G. 2005. Nonindigenous Herpetofauna of Florida: Patterns of Richness and Case Studies of the Impacts of the Tadpoles of Two Invasive Amphibians, Osteopilus septentrionalis and Bufo marinus. Unpublished Ph.D. Dissertation, University of Tennessee, Knoxville, Tennessee.

Stroud, J.T. 2013. Knight Anoles: Nocturnal activity facilitated by artificial lights? Anole Annals. <http://www.anoleannals.org/2013/06/29/knight-anoles-nocturnal-activity-facilitated-by-artificial-lights/>.

Stroud, J.T. and T. Sanger. 2020. Hemidactylus mabouia (Wood Slave). Predation. Herpetological Review 51: 125.

Teixeira, R.L. and M. Giovanelli. 1999. Ecologia de Tropidurus torquatus (Sauria: Tropiduridae) da restinga de Guriri, São Mateus, ES. Revista Brasileira de Biologia 59: 11-18.

Thawley, C.J., A.C. Battles, S.N. Michaelides, and J.J. Kolbe. 2017. Anolis equestris (Cuban Knight Anole). Prey. Herpetological Review 48: 183-184.

Thomas, R.A. 1976. A revision of the South American colubrid snake genus Philodryas Wagler, 1830. Unpublished Ph.D. thesis, Texas A\&M University, College Station, Texas.

Trageser, S.J., A. Wiscovitch, and P. Hamilton. 2018. Predation by an Antigua Bank Tree Anole, Anolis leachii (Duméril and Bibron 1837), on an introduced Tropical House Gecko, Hemidactylus mabouia (Moreau de Jonnés 1818). Reptiles \& Amphibians 25: 155.

Vargas Salinas, F. 2006. Breeding behavior and colonization success of the Cuban Treefrog Osteopilus septentrionalis. Herpetologica 62: 398-408.

Vecchi, M.B. and J.M. Harding. 2016. Hemidactylus mabouia (Tropical House
Gecko). Predation. Herpetological Review 47: 136-137.

Vieira, E, 2019. Dendroplex picus. BioFaces. <http://www.biofaces.com/ post/146912/arapacu-de-bico-branco/>.

Vieira, L.A. and R.L. Teixeira. 2008. Diet of Athene cunicularia (Molina, 1782) from a sandy coastal plain in southeast Brazil. Boletim do Museu de Biologia Mello Leitão 23: 5-14.

Voirin, C. 2016. Interspecific Interactions among Hemidactylus mabouia, Hemidactylus garnotii, and Osteopilus septentrionalis. Unpublished Thesis, Faculty of The Wilkes Honors College Requirements for the Degree of Bachelor of Arts in Liberal Arts and Sciences, Wilkes Honors College of Florida Atlantic University, Jupiter, Florida.

Vrcibradic, D. and A. Eisfeld. 2016. Predation on a tropical house gecko, Hemidactylus mabouia by a juvenile colubrid snake, Chironius bicarinatus, in a Brazilian Atlantic Rainforest area. Cuadernos de Herpetología 30: 75-77.

Vrcibradic, D. and C.F.D. Rocha. 2002. Ecology of Mabuya agilis (Raddi) (Lacertilia, Scincidae) at the restinga of Grumari, Rio de Janeiro, southeastern Brazil. Revista Brasileira de Zoologia 19 (Supl. 2): 19-29.

Wojnowski, D. and E. Selempo. 2005. Hemidactylus mabouia (Tropical House Gecko). Predation. Herpetological Review 36: 178-179.

Zanchi-Silva, D. and D.M. Borges-Nojosa. 2017. Hemidactylus mabouia (Tropical House Gecko). Predation. Herpetological Review 48: 438-439.

Zamprogno, C. and R.L. Teixeira. 1998. Hemidactylus mabouia (Tropical House Gecko). Cannibalism. Herpetological Review 29: 41-42. 